\title{
Directing effects in nitration of 1-adamantyl bearing aromatic ketones
}

\author{
Robert Vícha, ${ }^{a}$ * Ivo Kuřitka, ${ }^{b}$ Michal Rouchal, ${ }^{a}$ Veronika Ježková ${ }^{a}$ and Anja Zierhut ${ }^{a}$ \\ ${ }^{a}$ Department of Chemistry, Faculty of Technology, Tomas Bata University in Zlin, Náměstí T. G. \\ Masaryka. 275, 76272 Zlin, Czech Republic \\ ${ }^{b}$ Polymer Centre, Faculty of Technology, Tomas Bata University in Zlin, Náměstí T. G. \\ Masaryka. 275, 76272 Zlin, Czech Republic \\ E-mail: rvicha@ft.utb.cz
}

\begin{abstract}
Nitration of four 1-adamantyl bearing aromatic ketones with mixed acid, acetyl nitrate, silver nitrate and guanidine nitrate was studied under various conditions. The ketones with conjugated carbonyl group or with a benzyl group were examined and a considerably high amount of ortho isomer was observed in all cases. The proportion of ortho nitration showed the same trends for both examined groups of ketones. Unprecedently, the ortho isomer was formed quantitatively upon the reaction of 1-(1-adamantyl)-3-phenylpropan-2-one with acetyl nitrate in acetic anhydride. Influence of electronic, steric and complexation effect of carbonyl group on regioselectivity is discussed. An alternative reaction pathway including complexation of nitrating agent and a pre-equilibrium of protonated and nitronium coordinated carbonyl in particular is suggested to play crucial and general role in nitrations of aromatic carbonyl compounds.
\end{abstract}

Keywords: Aromatic ketones, 1-adamantyl, electrophylic substitution, nitration, regioselectivity

\section{Introduction}

The discovery of antiviral activity of 1-adamantylamine ${ }^{1}$ in 1964 hand in hand with the development of commercially applicable procedure for synthesis of adamantane, based on the Schleyer method ${ }^{2}$ published in 1957, induced the expansion of the application of adamantane moiety in various branches of chemistry, especially in chemistry of biologically active compounds. Adamantane bearing molecules were introduced as apoptosis inducers, ${ }^{3}$ potential anticancer drugs, ${ }^{4}$ substances for diabetes treatment, ${ }^{5}$ canabinoid receptor ligands, ${ }^{6}$ quinolines with anti-tuberculosis activity, ${ }^{7}$ compounds with antiviral properties, ${ }^{8}$ neuroprotective agents ${ }^{9}$ or drugs against Gaucher disease. ${ }^{10}$ 
This interest originates from the unique properties of the adamantane moiety, which can be introduced into potential or known biologically active compounds and in this way improve its properties. Due to high lipophilicity of adamantane, the transfer of modified drug through the cell membranes can be faster and thus the distribution becomes more effective. Also its solubility in aqueous media can be significantly increased by formation of inclusion complexes of adamantane cage with cyclodextrins. ${ }^{11,12}$ On the other hand, the introduction of bulky adamantane substituent into molecule too close to active site may lead to disappearing of desired activity. ${ }^{13}$ Therefore, adamantane derivatives with an appropriate spacer between adamantane moiety and binding site are needed for drug modification. Our research is aimed to modification of selected purine-based molecules. This is usually performed as a nucleophylic substitution of appropriate chloropurine using a useful amine. ${ }^{14}$ The most frequent method for anilines preparation is aromatic nitration followed by reduction.

Nitration has been one of the most studied and best understood organic reactions from mechanistic as well as preparative point of view. ${ }^{15}$ Beside conventional nitrating agents as nitric acid ${ }^{16,17}$ or nitric-sulfuric acid (mixed acid), many others agents were presented e.g. cerium(III) nitrate, ${ }^{18} \mathrm{~N}_{2} \mathrm{O}_{5}$ (ref. ${ }^{19}$ ), $\mathrm{NO}_{2} / \mathrm{O}_{3}$ mixture, ${ }^{20}$ acetyl nitrate, ${ }^{21}$ amyl nitrate ${ }^{22}$ (and other mixed anhydrides and esters), $N$-nitropyrazole, ${ }^{23}$ nitronium salts, silver nitrate in the presence of Lewis acids, $N$-nitropyridinium and $N$-nitroquinolinium and nitro or nitrito onium salts (for review see ref. $^{24}$ ), guanidinium nitrate, ${ }^{25 a}$ nitroguanidine, urea nitrate or nitrourea. ${ }^{25}$ However, due to the strong electron withdrawing effect of carbonyl group, the choice of the method for ketones nitration is rather limited. Despite of considerable synthetic importance of ketones, these are rarely included in mechanistic studies and papers dealing with the nitration methods of aromatic ketones are limited in scope of structurally differing ketones or/and nitrating conditions. We have recently examined nitration of four 1-adamantyl bearing ketones 1-adamantyl(phenyl)methanone (1), 2-(1-adamantyl)-1-phenylethanone (2), 1-(1-adamantyl)-2-phenylethanone (3) and 1-(1adamantyl)-3-phenylpropan-2-one (4) with structures shown in Figure 1. Although various methods were tested, only acetyl nitrate in acetic anhydride afforded desired products in excellent yields and was applicable for all examined ketones.

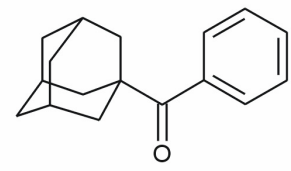

1

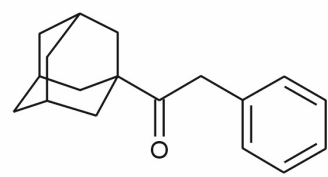

3

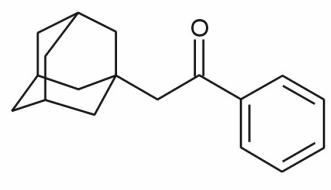

2

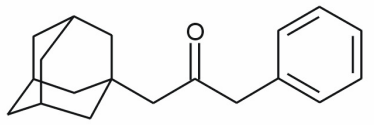

4

Figure 1. Structures of studied 1-adamantyl(phenyl)alkanones having $\alpha-(\mathbf{1}$ and $\mathbf{2})$ and $\beta$ - (3 and 4) positioned carbonyl. 
The complexity of electrophilic aromatic substitution causes difficulties in theoretical prediction of isomer distribution in product. Substituents with a simple structure might be handled in terms of Lewis structure models. Calculation on a higher level of theory is the only method of choice when a nontrivial early complex is involved in the reaction, as it occurs in

many cases. ${ }^{26}$ Quantum mechanical calculations could be employed in order to interpret not only directive effects of substituents but also their eventual complexation effects and, to some extent, reaction mechanism peculiarities as well. ${ }^{27}$

\section{Results and Discussion}

Mixture of sulfuric and nitric acids (mixed acid), nitric acid in acetic anhydride, silver nitrate with acetyl chloride in acetonitrile and guanidine nitrate in sulfuric acid were employed for nitration of four adamantane bearing ketones and acetophenone as a reference compound. 1Adamantyl phenyl ketone (1) was nitrated quantitatively with all the tested nitrating systems except silver nitrate (Table 1; entries 1-7). Mixed acid is known to be useful for nitration of stable ketones e.g. nitration of acetophenone was studied by Moodie et al., who observed a dominant ortho/meta orientation and perceptible influence of medium acidity upon the ortho/meta ratio. Although they describe the decrease of ortho/meta ratio from 0.37 in $80 \%$ sulfuric acid to 0.25 in $96 \% \mathrm{H}_{2} \mathrm{SO}_{4}$, they suppose acetophenone to be nitrated as the free base up to acidities at least as high as that represented by $90 \%$ sulfuric acid. ${ }^{28 a}$ Earlier paper by Baker and Moffitt ascribed similar observation to an increasing contribution of protonated form of ketone. ${ }^{28 \mathrm{~b}}$ We performed nitration with mixed acid at $30{ }^{\circ} \mathrm{C}$ and at $-15^{\circ} \mathrm{C}$ (Table 1; entries 1,2 ) with the ortho/meta/para regioisomers distribution 29/37/34 and 14/56/30 respectively. In terms of nitration of benzene ring bearing dipolar electron withdrawing group, the surprising proportion of para regioisomer was obtained. However, Barker et al. has observed similar results when pivalophenone was nitrated in fuming nitric acid or in $50 \% \mathrm{v} / \mathrm{v}$ sulfuric and nitric acids. ${ }^{29}$ Observed product distribution (Table 1, entry 20) has been attributed to a sterically induced noncoplanarity of the carbonyl group with the benzene ring. Such diminishing of the conjugation is contrary to the influence of the protonation, which was suggested to operate via resonance effect. An explanation based on pure electrostatic repulsion between protonated oxygen and positively charged nitrating agent may be also omitted because only one side of benzene ring would be efficiently blocked in the case of coplanar orientation of carbonyl and benzene or only one face of benzene ring would be blocked in the case of non-coplanar geometry. In the case of ketone $\mathbf{1}$, the ortho/meta ratio was also found to decrease from 0.78 to 0.25 at $30{ }^{\circ} \mathrm{C}$ and $-15{ }^{\circ} \mathrm{C}$ respectively while amount of para isomer remained invariable (Table 1, entries 1, 2). Similar temperature dependence was previously described by Zenitz et al., who studied the nitration of propiophenone with fuming nitric acid. ${ }^{30}$ Employment of nitric acid in acetic anhydride at $15{ }^{\circ} \mathrm{C}$ led to product distribution similar that of mixed acid at $30^{\circ} \mathrm{C}$ and combined yield of mononitrated products was almost quantitative as well. The ortho/para ratio increased from 0.7 
to unity when the reaction mixture was 20 times diluted (Table 1; entries 3,4). Acetyl nitrate generated in acetonitrile via the reaction of acetyl chloride with silver nitrate did not nitrate ketone $\mathbf{1}$ at any examined temperature and thus only starting material was detected in reaction mixture after $36 \mathrm{~h}$ under reflux. Finally, guanidine nitrate in conc. sulfuric acid showed excellent nitrating ability for ketone 1 . This system was employed at $0{ }^{\circ} \mathrm{C}$ and $25{ }^{\circ} \mathrm{C}$ respectively and quantitative yields of mononitrated derivatives were obtained at both temperatures within 15 min (Table 1; entries 6, 7). The ortho/meta ratio slightly decreased from 0.26 to 0.17 with lowering of temperature. Lower amount of ortho isomer was obtained in concert with strong acidity of used medium and was comparable with mixed acid at $-15^{\circ} \mathrm{C}$. It should be noted, that proportion of para isomer is invariably in the range $30-40 \%$ independently on the nitration conditions. It may indicate that energies of transition states of appropriate isomer pathways are similar when bulky substituent is present. Against this background, the associates of starting ketone with proton or nitronium compete and the former leads to meta whereas the latter to ortho isomer.

The nitric acid in acetic anhydride was the only applicable nitrating system for ketone 2. Under these conditions, the mononitrated regioisomers were obtained in quantitative yield with ortho/meta/para ratio of 30/65/5 (Table 1, entry 8). The ortho/meta ratio of 0.46 and low content of para isomer signified results expectable for similar acylbenzenes. Nitrating systems containing sulfuric acid provided rapid cleavage of ketone skeleton and only adamantane-1carboxylic acid was isolated in this case.

In the molecule of ketone 3 , the carbonyl is isolated from benzene ring by a methylene group to form a substituent displaying $\sigma$-inductive effect. Mixed acid did not give satisfactory results as it is shown in Table 1, entries 9, 10. Adamantane-1-carboxylic acid, bezaldehyde and nitrobenzaldehydes were detected by GC-MS analysis in mixture obtained at $30{ }^{\circ} \mathrm{C}$, which indicated cleavage of starting material. The lowering of temperature to $-15{ }^{\circ} \mathrm{C}$ led to smooth nitration with ortho/meta/para regioisomers obtained in ratio of $78 / 6 / 16$. However, the conversion of starting material was not satisfactory due to poor solubility of ketone $\mathbf{3}$ in reaction mixture. Nitric acid in acetic anhydride gave again quantitative yield of mononitrated products with ortho/meta/para ratio of 82/3/15 (Table 1, entry 11). Considerable high portion of ortho isomer exceeding statistical distribution was observed in mixed acid as well as in acetic anhydride. Strazzolini et al. has described similar results for various substrates with carbonyl isolated by one methylene group from benzene ring when nitric acid in $\mathrm{CH}_{2} \mathrm{Cl}_{2}$ was employed. This effect was attributed to nitration mechanism including an active nitrating agent complexed to carbonyl oxygen to form six-member ring transition state of lowest energy leading to formation of ortho isomer preferably. ${ }^{16,17}$ On the contrary, the opposite ortho/para ratio of value of 0.5 was obtained when nitroguanidine was employed in conc. sulfuric acid at $-15{ }^{\circ} \mathrm{C}$ (Table 1 , entry 14). Nitroguanidine was taken for this reaction instead guanidine nitrate because the application of latter was accompanied with water formation, which led to diluting and freezing of reaction mixture. Considering the mechanism of active nitrating agent formation, guanidine nitrate may be replaced by nitroguanidine without a significant influence upon the regioisomers proportion (ref. ${ }^{25 b}$; Table 1, entries 19, 20). The observed inversion of ortho/para ratio was 
attributed to high acidity of reaction medium rather than to nitrating agent origin. Surprisingly, ketone 3 underwent no reaction with silver nitrate and acetyl chloride in acetonitrile. In the respect of the smooth nitration of toluene under the same conditions, the strong electron withdrawing effect of the carbonyl group $(-I)$ seems to be responsible for observed unreactivity of ketone 3.

Table 1. Regioselectivity and conversion range in examined nitrations

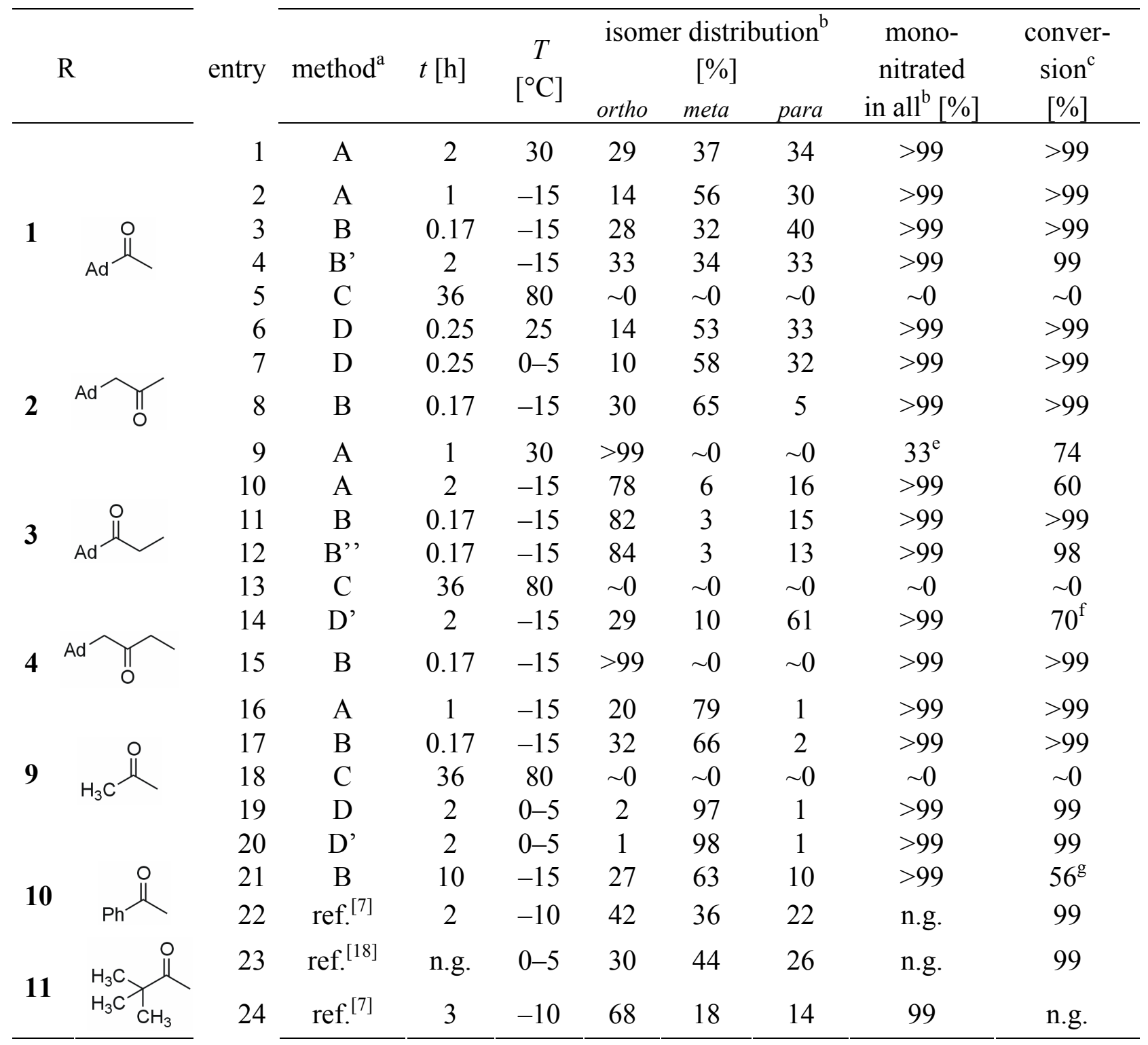

${ }^{a}$ For method details, see experimental section. ${ }^{b}$ Relative $\%$ according to GC. ${ }^{c}$ Estimated from the peak area of starting ketone according to GC. ${ }^{\mathrm{d}}$ Prolongation of reaction time led to oxidation of adamantane skeleton and hydroxyadamantane derivatives were detected. ${ }^{\mathrm{e}}$ Benzaldehyde (1\%) and its mononitrated derivatives ( $<1 \% o-, 23 \% m-, 6 \% p-)$ were also detected by GC-MS. ${ }^{\mathrm{f}}$ Adamantane-1-carboxylic acid $(225 \mathrm{mg}, 1.3 \mathrm{mmol})$ was isolated from crude product, isomer 
ratio of mononitrated ketone 3 was invariant during reaction period. ${ }^{\mathrm{g}}$ Conditions were not optimized, isomers ratio was invariant during reaction period. Ad $=1$-adamantyl, n.g. $=$ not given.

The ketone 4 was much more prone to decompose than the other ones and thus any nitrating system containing sulfuric acid was not applicable. However, nitric acid in acetic anhydride nitrated the ketone 4 quantitatively within $10 \mathrm{~min}$ and unprecedented portion of ortho regioisomer was detected in amount of more than $99 \%$ (Table 1, entry 14).

The similar isomers distribution under respective conditions obtained for acetophenone and benzophenone (Table 1, entries 16-21) rule out the key role of adamantyl substituent for observed ortho isomer portion.

Two principally different families of ketones containing carbonyl group and benzene ring conjugated or isolated were examined. Although the former is usually called as meta directing and the latter as ortho, para directing, the considerable high amount of ortho isomer was observed in most cases. Three explanations ${ }^{15 \mathrm{c}}$ for the relatively high proportion of ortho nitration were suggested for conjugated arylketones: a) the operation of a special mechanism e.g. specific association between carbonyl and nitrating species; b) ortho nitration is not unusual, but sometimes may be reduced by steric hindrance or c) the para position suffers special deactivation by the $-M$ effect. The complexation of active nitrating agent seems to be responsible for high ortho/para ratio observed in the case of $\beta$-ketones, ${ }^{16,17}$ but it should be noted that even inverse than statistical ortho/para ratio was obtained in strong acid medium (Table 1, entry 14). The trends in regioisomer ratio observed under comparable conditions are very similar for both groups of ketones. In either case, the increasing acidity of reaction medium decreased the ortho isomer proportion whereas content of meta isomer (for $\alpha$-ketones) or para isomer (for $\beta$-ketones) is increased. Analogous to pivalophenone, ${ }^{29}$ it is also reasonable to suppose lowering of resonance effect due to sterical hindrance of the bulky adamantane moiety in the case of ketone $\mathbf{1}$, but still, the ortho/meta ratio dropped from unity to 0.2 with increasing acidity of medium. This is indicative of lower resonance effects relationship to isomer distribution. Moreover, the high proportion of ortho isomer in the case of nitration of ketone $\mathbf{1}$ or pivalophenone does not support an explanation of reducing of ortho nitration by the bulkiness of the substituent. In our opinion, discussed facts support an alternative mechanism enhanced by competition between protonated and nitronium complexed carbonyl as it is shown in the Scheme 1. Under strong acid conditions, the protonated form of ketone is preferred and thus the proportion of complexed nitration agent is lowered and the extraordinary preference of ortho nitration disappears. 


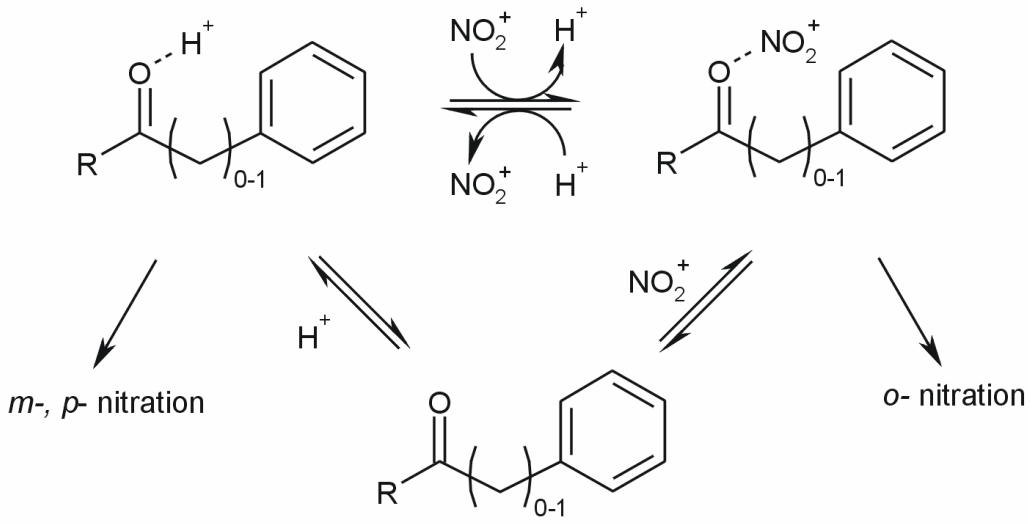

Scheme 1. Supposed pre-equilibrium of free, protonated and nitronium coordinated forms of aromatic ketones.

The decrease of acidity of reaction medium complies with complexation of carbonyl oxygen by nitrating agent, which may attack the proximate ortho position of the benzene ring preferably. Some other arguments for our suggestions came from theoretical calculations.

\section{Theoretical calculations}

For computational details and references see below (Computational methods section).

The structural and electronic properties of pristine molecules were studied at first (see Table 2). The calculations were carried out not only for parent molecules 1-4, 9, and 11 but also for protonated structures $\mathbf{1}$ and $\mathbf{9}$, considering the strong acidity of the reaction media when concentrated $\mathrm{H}_{2} \mathrm{SO}_{4}$ is used as a solvent. In the latter cases, two total energy minima were found for protonated structures having the proton coordinated to the $\mathrm{O}$ atom in the carbonyl group. The energy difference between two possible conformers (denoted with ${ }^{*}$ and ${ }^{* *}$ in Table 2 ) is in order of tens of $\mathrm{kJ} / \mathrm{mol}$, so there is a preference for the conformer with the $\mathrm{H}^{+}$facing the phenyl ring (about $99 \%$ according to Boltzman distribution). Natural bond orbital (NBO) analysis ${ }^{31}$ was carried out on all the optimized structures to obtain the natural atomic charges for neutral and charged compounds. Thus, the calculated values can be discussed in terms of Lewis structures and directive effects of substituents. The classical polar Ingold-Hudges mechanism reflects the charge distribution on the aromatic hydrocarbon in reactions involving product-determining transition state, which appears relatively early on the reaction coordinate. Then, according to the NBO atomic charges, electron withdrawing and donation effects are assessed for substituents in ketones 1, 2, 9 and $\mathbf{1 1}$ to be meta directing and in ketones $\mathbf{3}$ and $\mathbf{4}$ as ortho/para directing. The latter group of ketones shows much smaller differences in partial charge distribution than the first group, whereas the regioisomers distributions obtained just for species $\mathbf{3}$ and $\mathbf{4}$ were the most diverse. 
Table 2. C2-C6 NBO charges and $\theta(\mathrm{O} 1-\mathrm{C} 7-\mathrm{C} 1-\mathrm{C} 2)$ for calculated structures

\begin{tabular}{|c|c|c|c|c|c|c|c|}
\hline & \multirow{2}{*}{ structure } & \multicolumn{5}{|c|}{ carbon numbering related to ketone $\mathbf{1}$} & \multirow{2}{*}{$\theta\left[^{\circ}\right]$} \\
\hline & & 2 & 3 & 4 & 5 & 6 & \\
\hline 1 & & -0.185 & -0.240 & -0.216 & -0.241 & -0.210 & 10.89 \\
\hline $1^{*}$ & & -0.198 & -0.218 & -0.148 & -0.221 & -0.157 & 28.78 \\
\hline $1^{* *}$ & & -0.145 & -0.229 & -0.143 & -0.228 & -0.156 & 26.44 \\
\hline 2 & & -0.185 & -0.239 & -0.215 & -0.240 & -0.209 & -0.51 \\
\hline 3 & & -0.217 & -0.232 & -0.241 & -0.236 & -0.230 & n. a. \\
\hline 4 & & -0.231 & -0.229 & -0.240 & -0.232 & -0.238 & n. a. \\
\hline 9 & & -0.185 & -0.239 & -0.215 & -0.241 & -0.209 & -0.17 \\
\hline $9^{*}$ & & -0.161 & -0.220 & -0.122 & -0.226 & -0.135 & 7.24 \\
\hline $9^{* *}$ & & -0.081 & -0.269 & -0.071 & -0.269 & -0.100 & 0.01 \\
\hline 11 & & -0.184 & -0.240 & -0.215 & -0.241 & -0.208 & 7.53 \\
\hline
\end{tabular}

Ad =1-adamantyl; n. a. = not applicable.

Equilibrium geometry calculations give torsion angle values for the carbonyl group and the phenyl ring plane. Ketones 1 and $\mathbf{1 1}$ show the torsion angles $\mathrm{O} 1-\mathrm{C} 7-\mathrm{C} 1-\mathrm{C} 2$ of about $10.9^{\circ}$ and $7.5^{\circ}$. This is well explained by steric hindrance of their bulky substituents. Nevertheless, the comparison with nearly perfect planar $\left(0.04^{\circ}\right)$ acetophenone (9) indicates that the charge distribution over the $\mathrm{C}$ atoms in the phenyl ring is almost the same in all three of these compounds, so the moderate distortion of $\pi$-conjugated system over phenyl and carbonyl groups cannot be regarded as the reason for the observed differences in directivity considering the classical polar mechanism.

Results obtained for thermodynamically preferred protonated forms of ketones $\mathbf{1}^{*}$ and $\mathbf{9}^{*}$ imply different trends. For $1^{*}$, a large deviation from planarity is predicted (about $28.8^{\circ}$ ), for structure $9^{*}$ the torsion angle is smaller (about $7.2^{\circ}$ ) but with an impact on C2 to C6 charge distribution being very similar to that of $\mathbf{1}^{*}$. Distortion of planarity of carbonyl-phenyl groups 
decreases the level of conjugation, while the coordinated proton increases the withdrawing effect of the substituent group. The tendency to take up non-planar conformation if the compound is protonated might be significant for the important role of early stages of $\pi$-complex formation in the reaction. It is evident that partial charge distribution and equilibrium geometry optimization of the above initial molecules and protonated species enable the first insight into the nature of the examined system, but it cannot give a fully reliable prediction for its behavior in the case of $\mathrm{S}_{\mathrm{E}} \mathrm{Ar}$ reaction with substituents under consideration (1, $\mathbf{3}$ and $\mathbf{4})$.

The mechanism of aromatic nitration has been considered as a competition between two plausible extreme pathways represented by SET and classical polar Ingold-Hughes mechanism, where the capability to transfer an electron to $\mathrm{NO}_{2}{ }^{+}$determinate the prevalence of either one of these mechanisms. ${ }^{15 \mathrm{~d}}$ Frontier MO energies and symmetry have been considered to play significant role in both mechanisms. The preference of ortho and para position in benzene substituted by electron donating substituents has been attributed to HOMO with higher coefficients in ipso (ortho substitution occurs when ipso substituent is not a good leaving group via 1,2-shift of the $\mathrm{NO}_{2}$ group) and para positions and such nitrations are intimately related to the SET mechanism. Electron-donating substituents, related to ortho, para substitution, increase the energy of symmetric HOMO and thus SET becomes more favorable. Hence, ortho, para directing capability of a substituent may be drawn from the HOMO energy of appropriate substituted benzene. On the other hand, the antisymmetric HOMO has higher coefficients in ortho and meta in benzenes bearing electron-withdrawing group so, in agreement with IngoldHughes mechanism, the Wheeland intermediate occurs preferentially in the meta position due to minimizing repulsion between partial positive charges. Table 3 shows the HOMO energies calculated for selected aromatic compounds and ketones 1-4. Whereas the HOMO energy of benzaldehyde is lower than HOMO of benzene, all examined ketones $\mathbf{1 - 4}$ as well as acetophenone have HOMO energies higher than benzene. Moreover, considering electron density of HOMO with significantly high coefficient located on oxygen atom of carbonyl group (representative HOMO surfaces of ketones 2 and 4 shows Figure 2), the energy of HOMO does not seem to be relevant to SET probability in the case of any examined ketone (all of them should be prone to SET and be ortho/para directing from this point of view ${ }^{15 d}$ ). Still, if the SET would be considered, the oxygen atom is most likely the donor of electron rather than benzene ring and a SET intimate pair at the carbonyl oxygen should be formed in early stage of nitration. 

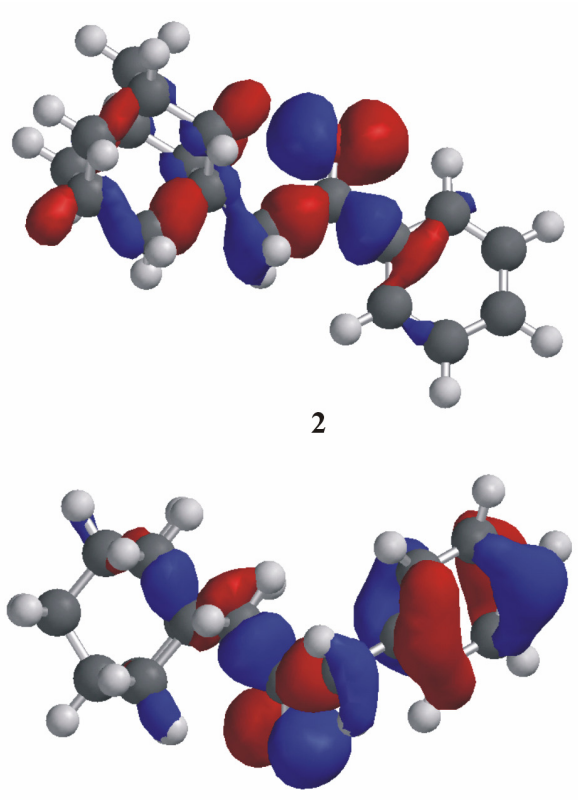

4

Figure 2. Optimized geometries for compounds $\mathbf{2}$ and $\mathbf{4}$ with representation of HOMO surface.

Table 3. Energies of HOMO for substituted benzenes $\mathrm{Ph}-\mathrm{R}[\mathrm{eV}]$

\begin{tabular}{|c|c|}
\hline $\mathrm{Ph}-\mathrm{R}$ & $E[\mathrm{eV}]$ \\
\hline$-\mathrm{NH}_{2}$ & -5.388 \\
\hline$-\mathrm{CH}_{2} \mathrm{COAd}(\mathbf{3})$ & -6.246 \\
\hline$-\mathrm{CH}_{2} \mathrm{COCH}_{2} \mathrm{Ad}(4)$ & -6.262 \\
\hline- COAd (1) & -6.476 \\
\hline$-\mathrm{COCH}_{2} \mathrm{Ad}(2)$ & -6.538 \\
\hline$-\mathrm{COCH}_{3}(\mathbf{9})$ & -6.720 \\
\hline$-\mathrm{H}$ & -6.721 \\
\hline$-\mathrm{CHO}$ & -6.944 \\
\hline$-\mathrm{NO}_{2}$ & -7.610 \\
\hline
\end{tabular}

In order to investigate the role of the substituent in the reaction mechanism, the formation of early complexes was modeled by searching for possible equilibrium geometries of starting molecules with nitronium cation. It is considered that these complexes are singly charged and have singlet multiplicity. The finding of equilibrium geometry and character of calculated complex depends on the starting position of the nitronium cation in respect to the phenyl ring of the ketone when the calculation could converge to more than one possible isomer. Hence, several meaningful initial assumptions have been tested for every examined compound, as it is intuitively understood when dealing with $o / m / p$ substituents. First, the initial geometry of a neutral compound was optimized by the $\mathrm{B} 3 \mathrm{LYP} / 6-31 \mathrm{G}^{* *}$, then the $\mathrm{NO}_{2}{ }^{+}$was introduced. 
Optimization procedures were initialized at starting positions of the nitronium in proximity of the $\mathrm{C} 1, \mathrm{C} 2, \mathrm{C} 3$ and $\mathrm{C} 4$ carbon at about $3 \AA$ over the benzene ring plane. Initial assumptions placing nitronium at a much longer distance from the phenyl ring were also employed, thus giving almost identical results as those beginning in proximal positions. The computation task failed in few cases when the distance was too long. In all cases the interaction between nitronium and the neutral molecule led to a loss of nitronium linearity, as the $\mathrm{ONO}$ angle (in range about $135^{\circ}-$ $140^{\circ}$ ) nearly approached the geometry of a nitro group (about $125^{\circ}$ ).

Table 4. Energies of $\sigma$ - and $\pi$-complexes of ketones 1-4

\begin{tabular}{ccccc}
\hline position $^{\mathrm{a}}$ & $\mathbf{1}$ & $\mathbf{2}$ & $\mathbf{3}$ & $\mathbf{4}$ \\
\hline \multicolumn{5}{c}{$\pi$-complexes energies $\left[\mathrm{kJ} \cdot \mathrm{mol}^{-1}\right]$} \\
1 & -164.5 & -151.2 & -217.9 & -148.6 \\
2 & -166.2 & -157.8 & -228.3 & -215.8 \\
3 & -154.9 & -148.4 & -194.4 & -193.4 \\
4 & -165.5 & -143.3 & -220.2 & -193.0 \\
5 & -156.6 & -145.6 & $\rightarrow 3^{\mathrm{b}}$ & $\rightarrow 3^{\mathrm{b}}$ \\
6 & -149.3 & -145.8 & $\rightarrow 2^{\mathrm{b}}$ & $\rightarrow 2^{\mathrm{b}}$ \\
\multicolumn{5}{c}{} \\
2 & -178.7 & -152.0 & -213.3 & -200.4 \\
3 & -159.4 & -150.8 & -212.2 & -199.5 \\
4 & -165.7 & -153.2 & -234.3 & -204.9 \\
5 & -166.3 & -134.6 & - & - \\
6 & -161.9 & -138.1 & - & - \\
\hline
\end{tabular}

${ }^{\mathrm{a}}$ Numbering is analogous to ketone $\mathbf{1}$ in Table $1 .{ }^{\mathrm{b}}$ Dihedral angle $\mathrm{O} 1-\mathrm{C} 7-\mathrm{C} 1-\mathrm{C} 2$ overturned and position 6 became 2 and 5 became 3 during optimization process.

The energies of $\sigma$-complexes and $\pi$-complexes were calculated for ketones 1-4 (see Table 4). A sum of total energies of the nitronium cation and the respective compound 1-4 is set as a reference level in order to estimate the energetic contribution of nitronium complex formation. In general, in the molecules of ketones $\mathbf{1}$ and $\mathbf{2}$, the two ortho as well as meta positions are not chemically equivalent due to proximity of carbonyl oxygen. Thus the position closer to the oxygen atom in carbonyl group was assigned to be number 2. In the molecules of $\mathbf{3}$ and $\mathbf{4}$ the planes of benzene ring and carbonyl double bond are almost orthogonal, so the number of nonequivalent positions on the benzene ring is symmetrically reduced. In the former case, $\sigma$ complexes as well as $\pi$-complexes at position 2 and 3 have significantly lower energies than at respective positions 6 and 5. Therefore $\pi$-complex where $\mathrm{NO}_{2}{ }^{+}$is oriented at the same side like carbonyl oxygen is thermodynamically preferred and taken for further consideration. The energy of $\pi$-complex correlates very well with observed isomer distribution in moderate acid medium 
for ketones 2-4. These observations indicate that early $\pi$-complex-like transition state of highest energy controls rate as well as isomer distribution and carbonyl oxygen significantly participate on its structure as an electron donor. Considered ortho directed complexes of ketones 1-4 with $\mathrm{NO}_{2}{ }^{+}$including representation of HOMO coefficients are depicted in Figure 3. The symmetrical HOMO with higher coefficients in ipso and para positions was suggested to be responsible for ortho and para substitution when electron donating substituent is present on benzene ring. The energies of ipso oriented $\pi$-complex are considerably higher than energies for corresponding ortho and para complexes in the case of ketones 3 and 4, whereas ortho oriented $\pi$-complex energies are the lowest. In respect thereof, carbonyl oxygen assisted ortho $\pi$-complex is rather related to ortho substitution than 1,2-shift of $\mathrm{NO}_{2}$. In addition, ketone 4 has energy of ortho $\pi$ complex significantly lower than energy of $\pi$-complexes in other positions, which is in good relationship with the only isolated ortho isomer in this case. From this point of view, the 1adamantanoyl group in ketone 1 seems to be ortho, para directing with lowest energy of $\pi$ complexes in positions 2 and 4.
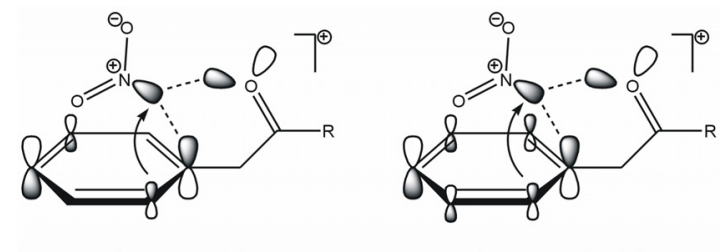

ketone $4 \mathrm{R}=\mathrm{CH}_{2} \mathrm{Ad}$

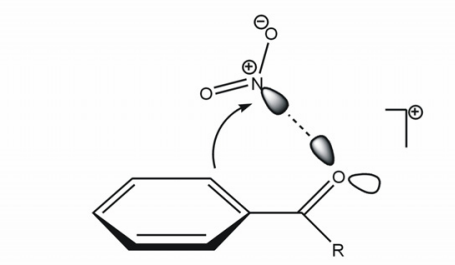

ketone $1 \mathrm{R}=\mathrm{Ad}$, ketone $2 \mathrm{R}=\mathrm{CH}_{2} \mathrm{Ad}$, ketone $9 \mathrm{R}=\mathrm{CH}_{3}$

Figure 3. Supposed schemes of nitronium complexes with examined compounds involving LUMO of nitronium ion and HOMO of aromatic ketone. Ad = 1-adamantyl.

The role of carbonyl oxygen and $\mathrm{NO}_{2}{ }^{+}$interaction is illustrated in the case of ketone $\mathbf{3}$. Two additional energy minima were distinguished, which demonstrate delivering of nitronium ion from being attracted by carbonyl oxygen to ortho position on benzene ring. Significant structural parameters are fluently changing as it is described in Table 5. First and second optimized geometry represent $\pi$-complex-like structures and the third and fourth structure shows transformation pathway from $\pi$-complex to $\sigma$-complex-like geometries. The change from early $\pi$ complex coordinated to $\mathrm{O}$ atom to the $\sigma$-complex is seen from gradual increase of $\mathrm{O} 1-\mathrm{N}$ and decrease of $\mathrm{C} 2-\mathrm{N}$ distance. The $\mathrm{ONO}$ angle decreases together with the rotation and shift of the $\mathrm{NO}_{2}$ group from $\pi$-like to $\sigma$-like position manifesting thus increase in bonding interaction. 
Table 5. Energies and selected geometric parameters of minimized structures participating on nitronium delivery to ortho position in ketone 3

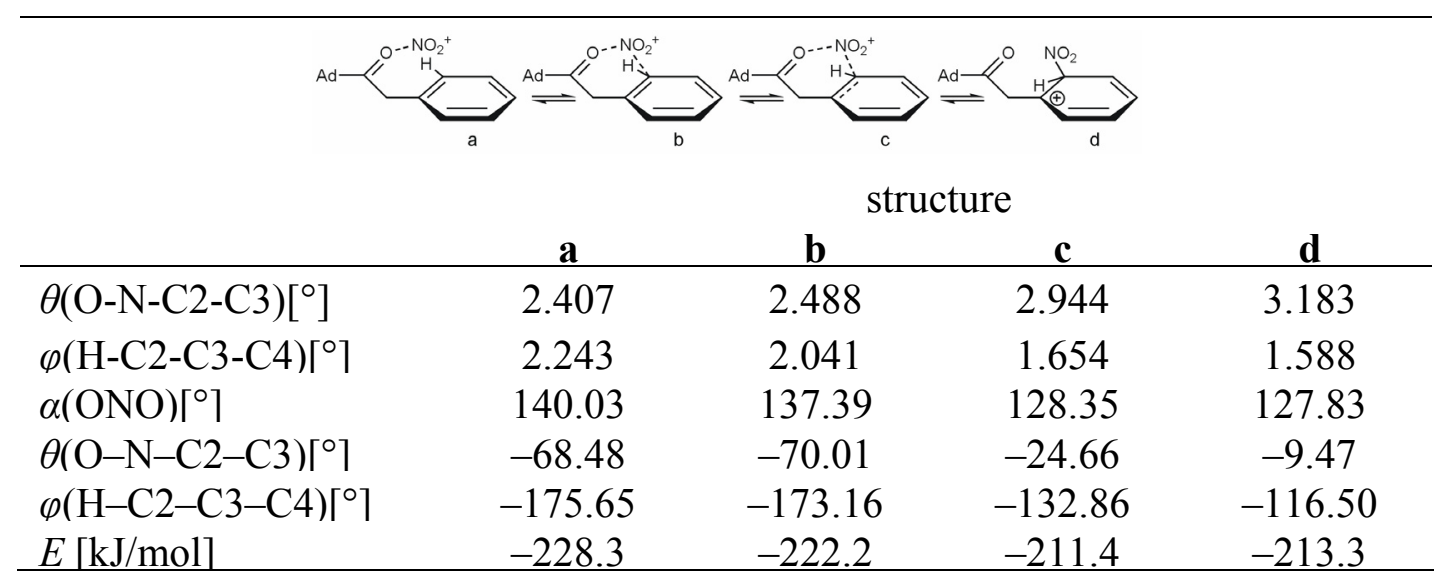

\section{Conclusions}

Pursuant to our results and related data from the literature, it can be concluded that the carbonyl at the $\alpha$ as well as at the $\beta$ positions to the phenyl ring posses the significant influence upon regioselectivity of aromatic nitration via complexation of nitrating agent. Observed enhancement of ortho/meta ratio with increasing temperature or decreasing acidity of the reaction medium, can be explained by formation of the nitronium or proton complex with the carbonyl of ketone and establishment of pre-equilibrium included both this form and its mutual competition. Thereafter, the increase of the nitronium complex concentration leads to an increase of the amount of orthonitro regioisomer in product. The best correlation between theoretical calculations and observed isomer distribution is obtained when NBO charges related to classical polar Ingold-Hudges mechanism and energies of $\pi$-complexes related to alternative carbonyl oxygen promoted pathway is considered together. Hence, formation of a nitronium complex preceding or alternating conventional $\pi$-complex seems to be responsible for the observed high amount of ortho isomer in nitration of both phenyl and benzyl ketones.

\section{Experimental Section}

General. Nitric acid (68\%), sulfuric acid (98\%), acetic anhydride and benzoyl chloride were purchased from commercial sources in analytical quality and were used without further purification. Adamantane-1-carbonyl chloride, ${ }^{32}$ phenylacetyl chloride ${ }^{33}$ and nitroguanidine ${ }^{34}$ were prepared following literature procedures. Guanidine nitrate was prepared by reaction of guanidine carbonate with equimolar amount of nitric acid in water. Crude product was crystallized from water. Elemental analyses were run on Thermo Fisher Scientific Flash EA 1112. Melting points are uncorrected. Retention factors $(R f)$ were determined using TLC plates 
Alugram Sil G/UV from Machrey-Nagel and petroleum ether/ethyl acetate v/v (system I - 8/1; system II - 4/1) as mobile phase. For separation on column the Silica gel 60 (70-230 mesh) from Fluka was used. NMR spectra were recorded at $300\left({ }^{1} \mathrm{H}\right)$ and $75.5\left({ }^{13} \mathrm{C}\right) \mathrm{MHz}($ Bruker AM-300) at $303 \mathrm{~K}$, using $\mathrm{CDCl}_{3}$ as a solvent and as an internal standard. The IR spectra were recorded with FT-IR instrument Mattson 3000 in $\mathrm{KBr}$ disc. GC-MS analyses were run on a Shimadzu QP-2010 instrument with integrated MS library NIST 02. Supelco SLB-5ms (30 m, $0.25 \mathrm{~mm})$ column and He as carrier gas at constant linear velocity $\left(38 \mathrm{~cm} \cdot \mathrm{s}^{-1}\right)$ were used; GC method: 100 ${ }^{\circ} \mathrm{C} / 7 \mathrm{~min}, 25{ }^{\circ} \mathrm{C} / \mathrm{min}$ to $250{ }^{\circ} \mathrm{C}$, hold for required time, IS $200{ }^{\circ} \mathrm{C} / 70 \mathrm{eV}$. Only $\mathrm{m} / \mathrm{z}$ signals exceeding relative abundance of $5 \%$ are listed. Regioisomers ratios in Table 1 are based on GCMS analyses. Each reaction reported in Table 1 was repeated at least twice with reproducibility of $\mathrm{GC}$ ratios being within 5\% for main component.

Ketones 1-4 were prepared from corresponding Grignard reagent and acyl chloride following literature procedure. ${ }^{32}$ In all cases the required ketones were accompanied by corresponding Grignard cross-coupling hydrocarbon products easily removable using column chromatography (hexane:ethyl acetate (gradient 1:0 to 8:1), silica gel). Any other side products were not observed. Spectral data for ketones 1 (yield 80\%), 2 (yield 92\%) and 3 (yield 84\%) corresponds with literature. ${ }^{35-37}$

1-(1-Adamantyl)-3-phenylpropan-2-one (4) was isolated as colorless crystals (yield 91\%, m.p. $=30-32{ }^{\circ} \mathrm{C}$, composition: calculated $85.03 \% \mathrm{C}, 9.01 \% \mathrm{H}$; exp. 84.85\% C, 9.12\% H). ${ }^{1} \mathrm{H}$ NMR $\left(\mathrm{CDCl}_{3}\right): \delta=1.66-1.74\left(\mathrm{~m}, 12 \mathrm{H}, \mathrm{CH}_{2}(\mathrm{Ad})\right), 1.98$ (m, 3H, $\left.\mathrm{CH}(\mathrm{Ad})\right), 2.24$ (s, 2H, $\left.\mathrm{AdCH}_{2} \mathrm{CO}\right)$, 3.69 (s, 2H, $\left.\mathrm{PhCH}_{2} \mathrm{CO}\right), 7.19-7.22(\mathrm{~m}, 2 \mathrm{H}, \mathrm{Ph}), 7.28-7.35$ (m, 3H, Ph) ppm. ${ }^{13} \mathrm{C} \mathrm{NMR}\left(\mathrm{CDCl}_{3}\right)$ : $\delta=28.8(\mathrm{CH}), 33.8(\mathrm{C}), 36.9\left(\mathrm{CH}_{2}\right), 42.6\left(\mathrm{CH}_{2}\right), 52.8\left(\mathrm{AdCH}_{2} \mathrm{CO}\right)$, 55.2( $\left.\mathrm{PhCH}_{2} \mathrm{CO}\right), 127.0(\mathrm{CH})$, 128.8(CH), 129.7(CH), 134.4(C), 208.0(CO) ppm. IR (KBr): 3057(w), 3032(w), 2899-2846(s), 1708(s), 1601(w), 1496(m), 1452(m), 1403(w), 1353(m), 1341(m), 1315(m), 1255(m), 1107(m), 1077(m), 1051(m), 920(w), 743(s), 700(s), 867(w), 674(w) $\mathrm{cm}^{-1}$. MS: 41(6), 67(6), 77(5), 79(14), 81(5), 91(21), 93(13), 107(7), 135(100), 136(11), 149(11), 177(28), $\mathrm{M}^{+} 268(1) \mathrm{m} / \mathrm{z}(\%)$.

\section{General nitration methods}

Method A. Appropriate ketone $(4.15 \mathrm{mmol})$ was added in small portions into $2 \mathrm{~mL}$ of conc. sulfuric acid at temperature below $0{ }^{\circ} \mathrm{C}$. The mixture of sulfuric acid $(0.5 \mathrm{~mL})$ and nitric acid $(0.33 \mathrm{~mL}, 4.77 \mathrm{mmol})$ was added at $30^{\circ} \mathrm{C}$ or $-15^{\circ} \mathrm{C}$. After completion of the reaction according to GC or TLC the mixture was diluted with water and extracted three times with diethyl ether. Organic portions were combined, dried over $\mathrm{Na}_{2} \mathrm{SO}_{4}$ and evaporated to yield crude product.

Method B. Starting acetyl nitrate was prepared by treating of $10 \mathrm{~mL}$ acetic anhydride and nitric acid $(4.1 \mathrm{~mL})$ in presence of catalytic amount of sulfuric acid $(0.2 \mathrm{~mL})$. The mixture of nitric acid and sulfuric acid was carefully added into $\mathrm{Ac}_{2} \mathrm{O}$ dropwise at temperature about $-15{ }^{\circ} \mathrm{C}$. Generally, mixtures of acetic anhydride with nitric acid are known to be explosible. We performed preparation of acetyl nitrate as well as consecutive nitration in double coated $50 \mathrm{~mL}$ 
reaction flask with external cooling device in maximum scale of $0.01 \mathrm{~mol}$ (calculated to starting ketone). Internal temperature of reaction mixture was permanently monitored and addition of acids mixture was temperature-controlled. The reaction displayed perceptible induction period and we strongly recommend not to add more than $20 \%$ (vol) of acids mixture unless rapid temperature change is observed. After this period, each drop of acids mixture into cooled reaction mixture increased temperature significantly. Subsequently, the solution of starting ketone $\left(4.15 \mathrm{mmol}\right.$ ) in 4-10 $\mathrm{mL} \mathrm{Ac} 2 \mathrm{O}$ (depending on the ketone solubility) was added at $-15{ }^{\circ} \mathrm{C}$ dropwise during $20 \mathrm{~min}$. This step was not accompanied with high heat production. The starting material was consumed usually within $10 \mathrm{~min}$ (according to GC or TLC), the reaction was quenched by addition of crushed ice and colorless or pale yellow solid precipitated. Water dispersion was extracted with diethyl ether $(5 \times 30 \mathrm{~mL})$, collected portions was treated with water $(2 \times 30 \mathrm{~mL})$, twice with $1.6 \mathrm{M} \mathrm{K} \mathrm{K}_{2} \mathrm{CO}_{3}$ solution (to basic $\mathrm{pH}$ ) and dried over anhydrous $\mathrm{K}_{2} \mathrm{CO}_{3}$ for two days. Solvent was evaporated and regioisomers were separated from the mixture by column chromatography using silica gel and appropriate mobile phase.

Method B'. Like B but acetyl nitrate was prepared in $200 \mathrm{~mL}$ of acetic anhydride.

Method B', Like B without sulfuric acid.

Method C. The starting material $(4.15 \mathrm{mmol})$ was added into the solution of silver nitrate (4.15 $\mathrm{mmol})$ in acetonitrile $(10 \mathrm{~mL})$. The mixture was refluxed under inert gas for $20 \mathrm{~min}$ and solution of acetyl chloride $(4.15 \mathrm{mmol})$ in acetonitrile $(2 \mathrm{~mL})$ was added dropwise. The mixture was stirred under reflux for additional $36 \mathrm{~h}$ and reaction progress was monitored by GC-MS.

Method D and D'. (modified literature procedure $\left.{ }^{25 b}\right)$ : Guanidine nitrate (4.57 mmol) or nitroguanidine (method D') was carefully added to the vigorously stirred solution of starting ketone $(4.15 \mathrm{mmol})$ in sulfuric acid $(96 \%, 7 \mathrm{~mL})$ at required temperature (see Table 1$)$. After the addition completing, the stirring was continued and the reaction progress was monitored by GCMS.

\section{Nitration of ketone 1}

All three regioisomers were isolated from crude mixture (entry 3 in Table 1) using column chromatography (system I) as a colorless solid, calculated composition $71.56 \% \mathrm{C}, 6.71 \% \mathrm{H}$, $4.91 \% \mathrm{~N}$.

1-Adamantyl-(2-nitrophenyl)methanone (5a). Yield $325 \mathrm{mg}(27 \%), \mathrm{m} . \mathrm{p} .=123-125^{\circ} \mathrm{C}, R f=$ 0.21 , exp. composition: $71.69 \% \mathrm{C}, 6.56 \% \mathrm{H}, 5.21 \% \mathrm{~N} .{ }^{1} \mathrm{H} \mathrm{NMR}\left(\mathrm{CDCl}_{3}\right): \delta=1.73\left(\mathrm{~m}, 6 \mathrm{H}, \mathrm{CH}_{2}\right.$ (Ad)), 1.95 (m, 6H, $\mathrm{CH}_{2}$ (Ad)), 2.04 (m, 3H, CH(Ad)), 7.28 (d, J=7.3 Hz, 1H, Ph), 7.58 (dd, $J_{1}$ $\left.=7.6, J_{2}=8.0,1 \mathrm{H}, \mathrm{Ph}\right), 7.73\left(\mathrm{dd}, J_{1}=7.6, J_{2}=7.3,1 \mathrm{H}, \mathrm{Ph}\right), 8.23(\mathrm{~d}, J=8.0,1 \mathrm{H}, \mathrm{Ph}) \mathrm{ppm} .{ }^{13} \mathrm{C}$ NMR $\left(\mathrm{CDCl}_{3}\right): \delta=28.2(\mathrm{CH}), 36.6\left(\mathrm{CH}_{2}\right), 38.8\left(\mathrm{CH}_{2}\right), 47.7(\mathrm{C}), 124.6(\mathrm{CH}), 127.4(\mathrm{CH})$, 129.6(CH), 134.5(CH), 137.8(C), 209.8(CO) ppm. IR (KBr): 3094(w), 3075(w), 3035(w), $2922-$ 
2853(s), 1699(s), 1613(w), 1572(w), 1524(s), 1451(m), 1343(s), 1313(w), 1273(w), 1228(m), 988(w), 949(w), 933(w), 858(m), 795(m), 760(m), 710(m), 671(w), 639(m) cm $\mathrm{cm}^{-1}$ MS: 41(6), 55(6), 67(9), 77(10), 79(26), 81(7), 91(8), 93(25), 107(15), 135(100), 136(11) m/z (\%).

1-Adamantyl-(3-nitrophenyl)methanone (5b). Yield $358 \mathrm{mg}(30 \%), \mathrm{m} . \mathrm{p} .=73-76{ }^{\circ} \mathrm{C}, R f=$ 0.36, exp. composition: $71.48 \% \mathrm{C}, 6.89 \% \mathrm{H}, 5.08 \% \mathrm{~N} .{ }^{1} \mathrm{H} \mathrm{NMR}\left(\mathrm{CDCl}_{3}\right): \delta=1.74(\mathrm{~m}, 6 \mathrm{H}$, $\left.\mathrm{CH}_{2}(\mathrm{Ad})\right), 1.98\left(\mathrm{~m}, 6 \mathrm{H}, \mathrm{CH}_{2}(\mathrm{Ad})\right), 2.08$ (s, 3H, $\mathrm{CH}(\mathrm{Ad}), 7.56$ (dd, $J_{1}=7.6, J_{2}=7.3,1 \mathrm{H}, \mathrm{Ph}$ ), $7.81(\mathrm{~d}, J=7.3,1 \mathrm{H}, \mathrm{Ph}), 8.27(\mathrm{~d}, J=7.6,1 \mathrm{H}, \mathrm{Ph}), 8.36(\mathrm{~s}, 1 \mathrm{H}, \mathrm{Ph}) \mathrm{ppm} .{ }^{13} \mathrm{C} \mathrm{NMR}\left(\mathrm{CDCl}_{3}\right): \delta=$ 28.2( $(\mathrm{CH}), \quad 36.6\left(\mathrm{CH}_{2}\right), \quad 39.2\left(\mathrm{CH}_{2}\right), \quad 47.4\left(\mathrm{CH}_{2}\right), \quad 55.9\left(\mathrm{AdCH}_{2} \mathrm{CO}\right), \quad 122.3(\mathrm{CH}), \quad 125.0(\mathrm{CH})$, 129.5(CH), 133.2(CH), 141.0(C), 207.8(CO) ppm. IR (KBr): 3120(w), 3084(w), 2962-2848(s), 1665(s), 1612(m), 1528(s), 1349(s), 1279(w), 1261(w), 1231(m), 1083(w), 1001(m), 967(w), 938(w), 903(w), 802(w), 711(s), 674(m), 643(w) $\mathrm{cm}^{-1}$. MS: 41(5), 55(5), 67(8), 76(6), 77(7), 79(21), 81(6), 91(6), 93(20), 107(12), 135(100), 136(11), $\mathrm{M}^{+}$285(1) m/z (\%).

1-Adamantyl-(4-nitrophenyl)methanone (5c). Yield $455 \mathrm{mg}(38 \%)$, m.p. $=122-123{ }^{\circ} \mathrm{C}, R f=$ 0.30, exp. composition: $71.39 \% \mathrm{C}, 6.63 \% \mathrm{H}, 5.06 \% \mathrm{~N} .{ }^{1} \mathrm{H}$ NMR $\left(\mathrm{CDCl}_{3}\right): \delta=1.70-1.81(\mathrm{~m}, 6 \mathrm{H}$, $\mathrm{CH}_{2}$ (Ad)), 1.97 (m, 6H, $\left.\mathrm{CH}_{2}(\mathrm{Ad})\right), 2.10$ (m, 3H, CH (Ad)), 7.60 (d, $\left.J=6.9,2 \mathrm{H}, \mathrm{Ph}\right), 8.25$ (d, $J=$ 6.9, 2H, Ph) ppm. ${ }^{13} \mathrm{C} \mathrm{NMR}\left(\mathrm{CDCl}_{3}\right): \delta=28.1(\mathrm{CH}), 36.6\left(\mathrm{CH}_{2}\right), 39.0\left(\mathrm{CH}_{2}\right), 47.3(\mathrm{C}), 123.5(\mathrm{CH})$, 127.9(CH), 143.1(C), 145.9(C), 209.3(CO) ppm. IR (KBr): 3107(w), 3077(w), 3044(w), 29062852(s), 1689(s), 1600(m), 1514(s), 1454(w), 1346(s), 1273(m), 1243(m), 1181(w), 1104(w), 991(w), 952(w), 933(w), 856(s), 830(m), 810(m), 714(m), 696(w), 665(w), 569(w), 469(w) cm ${ }^{-1}$. MS: 41(6), 55(5), 67(8), 77(8), 79(22), 81(6), 91(6), 93(20), 107(13), 135(100), 136(11), $\mathrm{M}^{+}$ $285(2) \mathrm{m} / \mathrm{z}(\%)$.

\section{Nitration of ketone 2}

All three regioisomers were isolated from crude mixture (entry 8 in Table 1) using column chromatography (system I) as a colorless solid, calculated composition $72.22 \% \mathrm{C}, 7.07 \% \mathrm{H}$, $4.68 \% \mathrm{~N}$.

2-(1-Adamantyl)-1-(2-nitrophenyl)ethanone (6a). Yield $352 \mathrm{mg}(28 \%), \mathrm{m} . \mathrm{p} .=94-97{ }^{\circ} \mathrm{C}, R f=$ 0.20, exp. composition: $71.98 \% \mathrm{C}, 7.18 \% \mathrm{H}, 4.81 \% \mathrm{~N} .{ }^{1} \mathrm{H}$ NMR $\left(\mathrm{CDCl}_{3}\right): \delta=1.71(\mathrm{~m}, 12 \mathrm{H}$, $\left.\mathrm{CH}_{2}(\mathrm{Ad})\right), 1.98(\mathrm{~m}, 3 \mathrm{H}, \mathrm{CH}(\mathrm{Ad})), 2.58$ (s, 2H, $\left.\mathrm{AdCH}_{2} \mathrm{CO}\right), 7.46$ (d, $\left.J=7.6,1 \mathrm{H}, \mathrm{Ph}\right), 7.58\left(\mathrm{dd}, J_{1}\right.$ $\left.=7.6, J_{2}=7.9,1 \mathrm{H}, \mathrm{Ph}\right), 7.70\left(\mathrm{dd}, J_{1}=J_{2}=7.6,1 \mathrm{H}, \mathrm{Ph}\right), 8.05(\mathrm{~d}, J=7.9,1 \mathrm{H}, \mathrm{Ph}) \mathrm{ppm} .{ }^{13} \mathrm{C} \mathrm{NMR}$ $\left(\mathrm{CDCl}_{3}\right): \delta=28.9(\mathrm{CH}), \quad 34.2(\mathrm{C}), \quad 37.0\left(\mathrm{CH}_{2}\right), \quad 42.6\left(\mathrm{CH}_{2}\right), \quad 55.9\left(\mathrm{AdCH}_{2} \mathrm{CO}\right), \quad 124.5(\mathrm{CH})$, 128.1(CH), 130.6(CH), 134.2(CH), 139.2(C), 140.1(C), 201.2(CO) ppm. IR (KBr): 3106(w), 3067(w), 3043(w), 2899-2851(s), 1716(m), 1694(s), 1600(m), 1516(s), 1453(w), 1343(s), 1320(m), 1291(m), 1266(m), 1177(w), 1142(w), 1106(w), 1010(w), 982(m), 846(m), 745(m), 718(m), 685(w) $\mathrm{cm}^{-1}$. MS: 41(40), 43(9), 50(7), 51(40), 52(7), 53(18), 55(34), 65(22), 67(44), 69(13), 76(25), 77(56), 78(18), 79(100), 80(18), 81(37), 91(65), 92(50), 93(94), 94(10), 104(21), 105(43), 106(13), 107(45), 119(19), 120(30), 121(43), 133(14), 134(8), 135(74), 136(14), 147(7), 149(8), 150(10), 151(29), 196(7), 210(11), 238(9), 252(7) m/z (\%).

2-(1-Adamantyl)-1-(3-nitrophenyl)ethanone (6b). Yield $788 \mathrm{mg}(63 \%), \mathrm{m} . \mathrm{p} .=79-80{ }^{\circ} \mathrm{C}, R f=$ 0.28, exp. composition: $72.35 \% \mathrm{C}, 7.23 \% \mathrm{H}, 4.42 \% \mathrm{~N} .{ }^{1} \mathrm{H} \mathrm{NMR}\left(\mathrm{CDCl}_{3}\right): \delta=1.67(\mathrm{~m}, 12 \mathrm{H}$, 
$\left.\mathrm{CH}_{2}(\mathrm{Ad})\right), 1.96$ (m, 3H, $\left.\mathrm{CH}(\mathrm{Ad})\right), 2.77$ (s, $\left.2 \mathrm{H}, \mathrm{AdCH}_{2} \mathrm{CO}\right), 7.67$ (dd, $J_{1}=8.3, J_{2}=7.91 \mathrm{H}, \mathrm{Ph}$ ), $8.27(\mathrm{~d}, J=8.3,1 \mathrm{H}, \mathrm{Ph}), 8.40(\mathrm{~d}, J=7.9,1 \mathrm{H}, \mathrm{Ph}), 8.76(\mathrm{~s}, 1 \mathrm{H}, \mathrm{Ph}) \mathrm{ppm} .{ }^{13} \mathrm{C} \mathrm{NMR}\left(\mathrm{CDCl}_{3}\right): \delta=$ 28.9(CH), 34.4(C), 36.9 $\left(\mathrm{CH}_{2}\right), 43.1\left(\mathrm{CH}_{2}\right), 51.6\left(\mathrm{AdCH}_{2} \mathrm{CO}\right), 123.4(\mathrm{CH}), 127.2(\mathrm{CH}), 129.9(\mathrm{CH})$, 134.0(CH), 140.3(C), 148.7(C), 198.0(CO) ppm. IR (KBr): 3090(w), 2903-2846(s), 1672(s), 1614(w), 1577(w), 1530(s), 1477(w), 1447(m), 1351(s), 1310(m), 1256(m), 1202(w), 1150(w), 1094(m), 1036(w), 925(w), 814(w), 731(m), 703(w), 667(w), 604(w) $\mathrm{cm}^{-1}$. MS: 41(19), 53(8), 55(15), 65(6), 67(21), 69(5), 76(23), 77(23), 78(8), 79(47), 80(9), 81(15), 91(27), 92(28), 93(42), 104(26), 105(12), 107(20), 119(8), 135(100), 136(12), 150(15), 252(6), 282(64), 283(13), $\mathrm{M}^{+}$ 299(3) $\mathrm{m} / \mathrm{z}(\%)$.

2-(1-Adamantyl)-1-(4-nitrophenyl)ethanone (6c). Yield $45 \mathrm{mg}(4 \%), \mathrm{m} . \mathrm{p} .=135-139{ }^{\circ} \mathrm{C}, R f=$ 0.33, exp. composition: $71.93 \% \mathrm{C}, 7.13 \% \mathrm{H}, 4.61 \% \mathrm{~N} .{ }^{1} \mathrm{H}$ NMR $\left(\mathrm{CDCl}_{3}\right): \delta=1.66(\mathrm{~m}, 12 \mathrm{H}$, $\mathrm{CH}_{2}$ (Ad)), 1.98 (m, 3H, CH(Ad)), 2.77 (s, $2 \mathrm{H}, \mathrm{AdCH}_{2} \mathrm{CO}$ ), 8.09 (d, $\left.J=8.3,2 \mathrm{H}, \mathrm{Ph}\right), 8.31$ (d, $J=$ 8.3, 2H, Ph) ppm. IR (KBr): 3106(w), 2899(s), 2851(s), 1694(s), 1600(m), 1532(m), 1517(s), 1453(w), 1395(w), 1343(s), 1320(m), 1291(m), 1266(m), 1202(m), 1177(w), 1142(m), 1106(w), 1010(m), 982(m), 846(m), 745(m), 718(m), 685(w) $\mathrm{cm}^{-1}$. MS: 40(5), 41(26), 42(13), 55(17), 65(8), 67(27), 76(15), 77(30), 79(61), 81(14), 91(35) 92(39), 93(55), 104(23), 105(8), 107(27), 120(33), 135(100), 136(10), 148(12), 252(9), 269(5), 282(33), $\mathrm{M}^{+}$299(<1) m/z (\%).

Nitration of ketone 3. Two regioisomers were isolated from crude mixture (entry 11 in Table 1) using column chromatography (system II) as a colorless solid, calculated composition $72.22 \% \mathrm{C}$, $7.07 \% \mathrm{H}, 4.68 \% \mathrm{~N}$.

1-(1-Adamantyl)-2-(2-nitrophenyl)ethanone (7a). Yield $980 \mathrm{mg}(79 \%), \mathrm{m} . \mathrm{p} .=144-145{ }^{\circ} \mathrm{C}$, $R f=0.39$, exp. composition: $72.45 \% \mathrm{C}, 6.98 \% \mathrm{H}, 4.62 \% \mathrm{~N} .{ }^{1} \mathrm{H} \mathrm{NMR}\left(\mathrm{CDCl}_{3}\right): \delta=1.78(\mathrm{~m}, 6 \mathrm{H}$, $\mathrm{CH}_{2}$ (Ad)), 1.96 (m, 6H, $\left.\mathrm{CH}_{2}(\mathrm{Ad})\right), 2.11$ (m, 3H, $\mathrm{CH}(\mathrm{Ad})$ ), 4.24 (s, 2H, $\left.\mathrm{PhCH}_{2} \mathrm{CO}\right), 7.22$ (d, $J=$ $7.6,1 \mathrm{H}, \mathrm{Ph}), 7.44\left(\mathrm{dd}, J_{1}=7.3, J_{2}=8.3,1 \mathrm{H}, \mathrm{Ph}\right), 7.56\left(\mathrm{dd}, J_{1}=7.6, J_{2}=7.3,1 \mathrm{H}, \mathrm{Ph}\right), 8.10(\mathrm{~d}, J$ $=8.3,1 \mathrm{H}, \mathrm{Ph}) \mathrm{ppm} .{ }^{13} \mathrm{C} \mathrm{NMR}\left(\mathrm{CDCl}_{3}\right): \delta=28.3(\mathrm{CH}), 36.8\left(\mathrm{CH}_{2}\right), 38.8\left(\mathrm{CH}_{2}\right), 42.5\left(\mathrm{PhCH}_{2} \mathrm{CO}\right)$, 45.2(C), 125.4(CH), 128.2(CH), $131.4(\mathrm{C}), 133.4(\mathrm{CH}), 133.7(\mathrm{CH}), 141.1(\mathrm{C}), 210.6(\mathrm{CO}) \mathrm{ppm}$. IR (KBr): 2902(s), 2849(s), 1699(s), 1611(w), 1577(w), 1519(s), 1449(w), 1418(w), 1343(s), 1193(w), 1159(m), 1013(m), 794(m), 762(m) $\mathrm{cm}^{-1}$. MS: 41(6), 55(5), 67(8), 77(9), 78(6), 79(20), 81(5), 91(8), 93(17), 107(9), 135(100), 136(12), 163(6), 194(8), 251(12), $\mathrm{M}^{+} 299(<1)$ $\mathrm{m} / \mathrm{z}(\%)$.

1-(1-Adamantyl)-2-(4-nitrophenyl)ethanone (7c). Yield $163 \mathrm{mg}(13 \%), \mathrm{m} . \mathrm{p} .=96-98{ }^{\circ} \mathrm{C}, R f=$ 0.46, exp. composition: $71.97 \% \mathrm{C}, 7.10 \% \mathrm{H}, 4.61 \% \mathrm{~N} .{ }^{1} \mathrm{H}$ NMR $\left(\mathrm{CDCl}_{3}\right): \delta=1.76(\mathrm{~m}, 6 \mathrm{H}$,

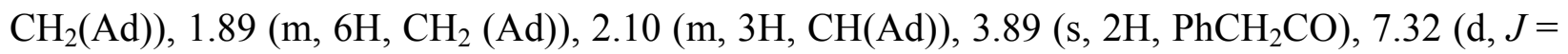
8.6, $2 \mathrm{H}, \mathrm{Ph}), 8.17(\mathrm{~d}, J=8.6,2 \mathrm{H}, \mathrm{Ph}) \mathrm{ppm} .{ }^{13} \mathrm{C} \mathrm{NMR}\left(\mathrm{CDCl}_{3}\right): \delta=28.1(\mathrm{CH}), 36.7\left(\mathrm{CH}_{2}\right)$, 38.4 $\left(\mathrm{CH}_{2}\right), 42.6\left(\mathrm{PhCH}_{2} \mathrm{CO}\right), 47.3(\mathrm{C}), 123.7(\mathrm{CH}), 129.3(\mathrm{CH}), 142.9(\mathrm{C}), 147.1(\mathrm{C}), 211.1(\mathrm{CO})$ ppm. IR (KBr): 3108(w), 3080(w), 2903-2848(s), 1700(s), 1604(m), 1516(s), 1451(m), 1347(s), 1139(w), 1155(w), 1108(w), 1011(m), 850(w), 818(w), 727(m), 688(w), 670(w) $\mathrm{cm}^{-1}$. MS: 41(5), 67(6), 77(7), 79(17), 91(7), 93(16), 107(9), 135(100), 136(13), 163(5), 194(5), 251(7) m/z $(\%)$. 
1-(1-Adamantyl)-2-(3-nitrophenyl)ethanone (7b). $R f=0.30$, this compound was not isolated in pure form and was identified using GC-MS. MS: 41(5), 55(5), 67(5), 77(5), 79(14), 91(5), 93(15), 107(7), 135(100), 136(13), 163(5), $\mathrm{M}^{+}$299(<1) m/z (\%).

\section{Nitration of ketone 4}

1-(1-Adamantyl)-3-(2-nitrophenyl)propan-2-one (8a). Pale yellow solid was isolated from reaction mixture (entry 15 in Table 1) after usual work up procedure using column chromatography (system II). Yield $1220 \mathrm{mg}(94 \%)$, m.p. $=74-77{ }^{\circ} \mathrm{C}, R f=0.37$, composition: calculated $72.82 \% \mathrm{C}, 7.40 \% \mathrm{H}, 4.47 \% \mathrm{~N}$, exp. $73.01 \% \mathrm{C}, 7.38 \% \mathrm{H}, 4.52 \% \mathrm{~N} .{ }^{1} \mathrm{H} \mathrm{NMR}\left(\mathrm{CDCl}_{3}\right)$ : $\delta=1.70\left(\mathrm{~m}, 12 \mathrm{H}, \mathrm{CH}_{2}(\mathrm{Ad})\right), 1.98(\mathrm{~m}, 3 \mathrm{H}, \mathrm{CH}(\mathrm{Ad})), 2.39$ (s, 2H, $\left.\mathrm{AdCH}_{2} \mathrm{CO}\right), 4.11$ (s, 2H, $\left.\mathrm{PhCH}_{2} \mathrm{CO}\right), 7.25(\mathrm{~d}, J=7.6,1 \mathrm{H}, \mathrm{Ph}), 7.45\left(\mathrm{dd}, J_{1}=7.6, J_{2}=7.9,1 \mathrm{H}, \mathrm{Ph}\right), 7.58\left(\mathrm{dd}, J_{1}=J_{2}=7.6\right.$, $1 \mathrm{H}, \mathrm{Ph}), 8.10(\mathrm{~d}, J=7.9,1 \mathrm{H}, \mathrm{Ph}) \mathrm{ppm} .{ }^{13} \mathrm{C} \mathrm{NMR}\left(\mathrm{CDCl}_{3}\right): \delta=28.8(\mathrm{CH}), 33.8(\mathrm{C}), 37.0\left(\mathrm{CH}_{2}\right)$, 42.6( $\left(\mathrm{CH}_{2}\right)$, 50.47( $\left.\mathrm{AdCH}_{2} \mathrm{CO}\right), 56.1\left(\mathrm{PhCH}_{2} \mathrm{CO}\right), 125.3(\mathrm{CH}), 128.4(\mathrm{CH}), 130.6(\mathrm{C}), 133.5(\mathrm{CH})$, 133.6(CH), 149.2(C), 205.1(CO) ppm. IR (KBr): 2903 (s), 2848(s), 1714(s), 1612(w), 1577(w), 1519(s), 1452(w), 1413(w), 1342(s), 1319(m), 1186(w), 1074(m), 863(m), 824(w), 791(m), 743(m), 709(m), 677(w) cm $\mathrm{cm}^{-1}$ MS: 41(5), 55(5), 67(6), 77(6), 79(13), 91(6), 93(14), 107(8), 135(100), 136(12), 149(7), 177(22), 265(6) m/z (\%).

\section{Nitration of acetophenone (9) and benzophenone (10)}

The meta regioisomers were isolated by crystallization from crude reaction mixtures obtained following method B, crude products were crystallized from ethanol yielded pale yellow needles. Spectral data for 3-nitroacetophenone ${ }^{38}$ and 3-nitrobenzophenone ${ }^{39}$ corresponded with the literature. Other isomers were not isolated in pure form and mass spectra were used for identification in comparison with the literature ${ }^{40}$ and NIST 02 library.

\section{Computational methods}

All calculations were carried out on isolated molecules, cations and complexes by using of density functional theory ${ }^{41}$ in this work. Equilibrium geometry, energy and optimization of all variables was performed at the B3LYP level of theory ${ }^{42}$ with a standard basis set $6-31 \mathrm{G}^{* *}$, which is identical to $6-31 G^{*}$, except it provides p-type polarization functions for hydrogen. ${ }^{43}$ The natural bond orbital (NBO) analysis ${ }^{42 \mathrm{~d}}$ was carried out on all the optimized structures to obtain the natural atomic charges for pristine and complex compounds. The computational model is employed in used molecular modeling software package TITAN. ${ }^{44}$ It combines computational capability of Jaguar (based on GAUSSIAN, Schrödinger Inc.) and SPARTAN (Wavefunction, Inc.) graphical user interface. The software was used to produce figures of molecular structures in Figure 3. 


\section{Acknowledgements}

This work was supported by Science Foundation of Czech Republic Grant No. 203/06/P362 and Ministry of Education, Youth and Sports of Czech Republic Grant No. MSM 7088352101.

\section{References}

1. Davies, W. L.; Grunert, R. R.; Haff, R. F.; McGahen, J. W.; Neumayer, E. M.; Paulshock, M.; Watts, J. C.; Wood, T. R.; Hermann, E. C.; Hoffmann, C. E. Science 1964, 144, 862.

2. Schleyer, P. von R. J. Am. Chem. Soc. 1957, 79, 3292.

3. (a) Farhana, L.; Dawson, M. I.; Leid, M.; Wang, L.; Moore, D. D.; Liu, G.; Xia, Z.; Fontana, J. A. Cancer Res. 2007, 67, 318. (b) Farhana, L.; Dawson, M. I.; Fontana, J. A. Cancer Res. 2005, 65, 4909.

4. Long, J.; Manchandia, T.; Ban, K.; Gao, S.; Miller, C.; Chandra, J. Cancer Chemother. Pharmacol. 2007, 59, 527.

5. (a) Raun, K.; von Voss, P.; Gotfredsen, C. F.; Golozoubova, V.; Rolin, B.; Knudsen, L. B. Diabetes 2007, 56, 8. (b) Augery, D. J.; Robl, J. A.; Betebenner, D. A.; Magnin, D. R.; Khanna, A.; Robertson, J. G.; Wang, A.; Simpkins, L. M.; Taunk, P.; Huang, Q.; Han, S.P.; Abboa-Offei, B.; Cap, M.; Xin, L.; Tao, L.; Tozzo, E.; Welzel, G. E.; Egan, D. M.; Marcinkeviciene, J.; Chang, S. Y.; Biller, S. A.; Kirby, M. S.; Parker, R. A.; Hamann, L. G. J. Med. Chem. 2005, 48, 5025. (c) Villhauer, E. B.; Brinkman, J. A.; Naderi, G. B.; Burkey, B. F.; Dunning, B. E.; Prasad, K.; Mangold, B. L.; Russell, M. E.; Hughes, T. E. J. Med. Chem. 2003, 46, 2774.

6. (a) Lu, D.; Meng, Z.; Thakur, G. A.; Fan, P.; Steed, J.; Tartal, C. L.; Hurst, D. P.; Reggio, P. H.; Deschamps, J. R.; Parrish, D. A.; George, C.; Järbe, T. U. C.; Lamb, R. J.; Makriyannis, A. J. Med. Chem. 2005, 48, 4576. (b) Stern, E.; Muccioli, G. G.; Bosier, B.; Hamtiaux, L.; Millet, R.; Poupaert, J. H.; Hénichart, J.-P.; Depreux, P.; Goossens, J.-F.; Lambert, D. M. J. Med. Chem. 2007, 50, 5471.

7. Nayyar, A.; Monga, V.; Malde, A.; Coutinho, E.; Jain, R. Bioorg. Med. Chem. 2007, 15, 626.

8. Motornaya, A. E.; Alimbarova, L. M.; Shokova, É. A.; Kovalev, V. V. Pharm. Chem. J. 2006, 40, 68 .

9. (a) Jensen, L. S.; Bølcho, U.; Egebjerg, J.; Strømgaard, K. ChemMedChem 2006, 1, 419. (b) Schlesinger, F.; Tammena, D.; Krampfl, K.; Bufler, J. Brit. J. Pharmacol. 2005, 145, 656. (c) Wang, Y.; Eu, J.; Washburn, M.; Gong, T.; Chen, H.-S. V.; James, W. L.; Lipton, S. A.; Stamler, J. S.; Went, G. T.; Porter, S. Curr. Alzheimer Res. 2006, 3, 201.

10. Yu, Z.; Sawkar, A. R.; Whalen, L. J.; Wong, C.-H.; Kelly, J. W. J. Med. Chem. 2007, 50, 94.

11. Cromwell, W. C.; Bystrom, K.; Eftink, M. R. J. Phys. Chem. 1985, 89, 326. 
12. van Bommel, K. J. C.; Metselaar, G. A.; Verboom, W.; Reinhoudt, D. N. J. Org. Chem. 2001, 66, 5405.

13. (a) Otyepka, M.; Kryštof, V.; Havlíček, L.; Siglerová, V.; Strnad, M.; Koča, J. J. Med. Chem. 2000, 43, 2506. (b) Barbarić, M.; Uršić, S.; Pilepić, V.; Zorc, B.; Hergold-Brundić, A.; Nagl, A.; Grdiša, M.; Pavelić, K.; Snoeck, R.; Andrei, G.; Balzarini, J.; De Clercq, E.; Mintas, M. J. Med. Chem. 2005, 48, 884.

14. (a) Fiorini, M. T.; Abell, C. Tetrahedron Lett. 1998, 39, 1827. (b) Wang, Y.; Metcalf, C. A.; Shakespeare, W. C.; Sundaramoorthi, R.; Keenan, T. P.; Bohacek, R. S.; van Schravendijk, M. R.; Violette, S. M.; Narula, S. S.; Dalgarno, D. C.; Haraldson, C.; Keats, J.; Liou, S.; Mani, U.; Pradeepan, S.; Ram, M.; Adams, S.; Weigele, M.; Sawyer, T. K. Bioorg. Med. Chem. Lett. 2003, 13, 3067. (c) Imbach, P.; Capraro, H.-G.; Furet, P.; Mett, H.; Meyer, T.; Zimmermann, J. Bioorg. Med. Chem. Lett. 1999, 9, 91. (d) Schow, S. R.; Mackman, R. L.; Blum, C. L.; Brooks, E.; Horsma, A. G.; Joly, A.; Kerwar, S. S.; Lee, G.; Shiffman, D.; Nelson, M. G.; Wang, X.; Wick, M. M.; Zhang, X.; Lum, R. T. Bioorg. Med. Chem. Lett. 1997, 7, 2697.

15. (a) Olah, G. A.; Malhotra, R.; Narang, S. C. Nitration Methods and Mechanisms; John Wiley \& Sons. Inc.: New York, 1989; and references therein. (b) Ono, N. The Nitro Group in Organic Synthesis; John Wiley \& Sons. Inc.: New York, 2001; and references therein. (c) Hoggett, J. G.; Moodie, R. B.; Penton, J. R.; Schofield, K. Nitration and Aromatic Reactivity; Cambridge University Press: Cambridge, 1971; and references therein. (d) Queiroz, J. F.; Carneiro, J. W. M.; Sabino, A. A.; Sparrapan, R.; Berlin, M. N.; Esteves, P. M. J. Org. Chem. 2006, 71, 6192. (e) Tahala, M.; Muro, E.; Ando, H.; Xu, Q.; Fujiwara, M.; Souma, Y.; Yamaguchi, Y. J. Org. Chem. 2000, 65, 2972.

16. Strazzolini, P.; Giumanini, A. G.; Runcio, A.; Scuccato, M. J. Org. Chem. 1998, 63, 952.

17. Strazzolini, P.; Giumanini, A. G.; Runcio, A. Tetrahedron Lett. 2001, 42, 1387.

18. Mellor, J. M.; Parkes, R.; Millar, R. W. Tetrahedron Lett. 1997, 38, 8739.

19. Bak, R. R.; Smallridge, A. J. Tetrahedron Lett. 2001, 42, 6767.

20. Suzuki, H.; Murashima, T. J. Chem. Soc. Perkin Trans. 1 1994, 903.

21. Stephens, C. E.; Felder, T. M.; Sowell, J. W.; Andrei, G.; Balzarini, J.; Snoeck, R.; De Clercq, E. Bioorg. Med. Chem. 2001, 9, 1123.

22. Tsang, S. M.; Paul, A. P.; DiGiaimo, M. P. J. Org. Chem. 1964, 29, 3387.

23. Olah, G. A.; Narang, S. C.; Fung, A. P. J. Org. Chem. 1981, 46, 2706.

24. Olah, G. A.; Narang, S. C.; Olah, J. A.; Lammertsma, K. Proc. Natl. Acad. Sci. USA 1982, $79,4487$.

25. (a) Ramana, M. M. V.; Malik, S. S.; Parihar, J. A. Tetrahedron Lett. 2004, 8681. (b) Oxley, J. C.; Smith, J. L.; Moran, J. S.; Canino, J. N.; Almog, J. Tetrahedron Lett. 2008, 4449.

26. Stock, L. M. Prog. Phys. Org. Chem. 1976, 12, 21.

27. Carrol, F. A. Perspectives on Structure and Mechanism in Organic Chemistry; Brooks Cole, 1998; and references therein. 
28. (a) Moodie, R. B.; Penton, J. R.; Schofield, K. J. Chem. Soc. B 1969, 578. (b) Baker, J. W.; Moffitt, W. G. J. Chem. Soc. 1931, 314.

29. Barker, S. D.; Norris, R. K.; Randles, D. Aust. J. Chem. 1981, 34, 1875.

30. Zenitz, B. L.; Hartung, W. H. J. Org. Chem. 1946, 11, 444.

31. (a) Foster, J. P.; Weinhold, F. J. Am. Chem. Soc. 1980, 102, 7211. (b) Reed, A. E.; Weinhold, F. J. Chem. Phys. 1983, 78, 4066. (c) Reed, A. E.; Weinstock, R. B.; Weinhold, F. J. Chem. Phys. 1985, 83, 735. (d) Carpenter, J. E.; Weinhold, F. J. Mol. Struct.(Theochem.) 1988, 169, 41.

32. Vícha, R.; Potáček, M. Tetrahedron 2005, 61, 83.

33. Wiesner, J.; Wissner, P.; Dahse, H.-M.; Jomaa, H.; Schlitzer, M. Bioorg. Med. Chem. 2001, 9, 785 .

34. Davis, T. L. Org. Synth. 1927, 7, 68.

35. Rieke, R. D.; Hanson, M. V.; Brown, J. D. J. Org. Chem. 1996, 61, 2726.

36. Rossi, R. A.; Pierini, A. B.; Borosky, G. L. J. Chem. Soc., Perkin Trans. 2, 1994, 2577.

37. Rakhimov, A. I.; Cherepanov, A. A. Russ. J. Org. Chem. 1999, 35, 1393.

38. Choi, H. Y.; Dae,Y. C. Org. Lett. 2003, 5, 411.

39. Zhao, B.; Lu, X. Org. Lett. 2006, 8, 5987.

40. Moraes, L. A. B.; Sabino, A. A.; Meurer, E. C.; Eberlin, M. N. J. Am. Soc. Mass Spectrom. 2005, 16, 431.

41. Parr, R. G.; Yang, W. Density-Functional Theory of Atoms and Molecules; Oxford University Press: New York, 1989.

42. (a) Lee, C.; Yang, W.; Parr, R. G. Phys. Rev. B, 1988, 37, 785. (b) Becke, A. D. Phys. Rev. A 1988, 38, 3098. (c) Kohn, W.; Becke, A. D.; Parr, R. G. J. Phys. Chem. 1996, 100, 12974.

43. (a) Hariharan, P. C.; Pople, J. A. Chem. Phys. Lett. 1972, 16, 217. (b) Hariharan, P. C.; Pople, J. A. Theor. Chim. Acta 1973, 28, 213; and following papers.

44. TITAN ${ }^{\circledR}$, version 1.0.5, Wavefunction, Inc. \& Schrödinger Inc., 2000. 